\title{
Can vitamin D protect against age-related macular degeneration or slow its progression?
}

\author{
Kai Kaarniranta1', Elzbieta Pawlowska², Joanna Szczepanska³, Aleksandra Jablkowska ${ }^{4}$ and \\ Janusz Blasiak ${ }^{5}$ 更
}

1Department of Ophthalmology, University of Eastern Finland, Kuopio 70211, Finland and Department of Ophthalmology, Kuopio University Hospital, Kuopio 70029, Finland; 2Department of Orthodontics, Medical University of Lodz, $92-216$ Łódź, Poland; ${ }^{3}$ Department of Pediatric Dentistry, Medical University of Lodz, 92-216 Łódź, Poland; 4Department of Infectious and Liver Diseases, W. Bieganski Hospital, 91-347 Łódź, Poland; ${ }^{5}$ Department of Molecular Genetics, Faculty of Biology and Environmental Protection, University of Lodz, 90-236 Łódź, Poland

\begin{abstract}
Dietary vitamin D plays an important role in maintaining proper vision. Age-related macular degeneration (AMD) is a complex eye disease with unknown pathogenesis. Studies on dietary supplementation and AMD occurrence and progression have produced conflicting results. In its advanced stage, AMD may be associated with apoptosis, pyroptosis or necroptosis of retinal cells. Vitamin $D$ has been reported to play a role in modulating each of these programmed death pathways. Vitamin $D$ is a modulator of the immune system and it acts synergistically with two members of the regulators of complement activation family $\mathrm{H}$ and $\mathrm{I}$, whose specific variants are the most important genetic factors for AMD pathogenesis. Angiogenesis is an essential component of the neovascular form of AMD, the most devastating type of the disease and vitamin $D$ is reputed to possess antiangiogenic properties. Cellular DNA damage response is weakened in AMD patients and so it is another process that can be modulated by vitamin D. Finally, impaired autophagy is claimed to play a role in AMD and emerging evidence suggests that vitamin D can influence autophagy. Therefore, several pathways of vitamin D metabolism and AMD pathogenesis overlap, suggesting that vitamin $D$ could modulate the course of AMD.
\end{abstract}

Key words: dietary vitamin D, age-related macular degeneration, autophagy, inflammation, immune response

Received: 30 April, 2019; revised: 31 May, 2019; accepted: 03 June, 2019; available on-line: 18 June, 2019

$\square$ e-mail: janusz.blasiak@biol.uni.lodz.pl

Acknowledgements of financial support: This work was supported by the Kuopio University Hospital (grant no. 5503743), the Finnish Eye Foundation and the Academy of Finland (grant no. 296840).

Abbreviations: 1,25(OH)2D, 1,25-dihydroxyvitamin D; 25(OH)D 25-hydroxyvitamin D; 8oxoG, 8-oxo-2'-deoxyguanosine; AMD, age-related macular degeneration; ATG, autophagy-related protein; CFH/I - complement factor H/l; CYP2R1, cytochrome P450 family 2 subfamily $\mathrm{R}$ member 1 ; DDR, DNA damage response; HTRA 1, high temperature requirement protein $A 1 ; \mathrm{IL}-1 \mathrm{a}$, interleukin-1a; LC3, microtubule-associated protein light chain 3; mTOR, mechanistic target of rapamycin; NLRP3, NLR (neural retina leucine zipper) family pyrin domain containing 3; RPE, retinal pigment epithelium; SNP, single nucleotide polymorphism; TGF- $\beta$, transforming growth factor- $\beta$; TNF-a, tumor necrosis factor- $\alpha$; VDR, vitamin D receptor

\section{INTRODUCTION}

\section{Age-related macular degeneration}

Age-related macular degeneration (AMD) is a complex eye disease destroying the macula, the part of the retina responsible for sharp central vision and it is the leading cause of vision loss in the elderly in many countries (Reibaldi et al., 2016). Although pathogenesis of AMD is largely unknown, an inappropriate diet can influence its occurrence and progression (Aoki et al., 2016; Broadhead et al., 2015; Everitt et al., 2006; Parekh et al., 2007; Seddon et al., 2011; Stevens et al., 2015). More detail on the role of diet in AMD pathogenesis is provided in a subsequent section.

AMD is an emerging medical problem as the number of people affected by AMD and the cost of medical care increase (Wong et al., 2004). In its advanced stage, the disease occurs in two basic forms: dry (non-neovascular) and wet (neovascular). Whereas there have been some successes in the treatment of wet AMD with inhibitors of vascular endothelial growth factor A (VEGFA), important for neovascularization, there is no remedy for the dry form of the disease (Maguire \& Campbell, 2010).

Genetic, environmental and life-style factors have been implicated in AMD pathogenesis (Fig. 1). AMD mainly affects individuals over 65 years old. Mutations in the genes coding for complement factors $\mathrm{H}$ and $\mathrm{I}$ as well as some other genes, including those participating in lipid metabolism, other components of the immune system, and parts of the vascular system, represent the main genetic risk factors for AMD (Lyzogubov et al., 2016). Studies conducted in the United States indicate that white race and female sex seem to be strongly associated with the occurrence of AMD - in 2010, 2.5\% of the white adults aged 50 or older had AMD, while the disease occurrence in blacks, Hispanics and people of other races was less than $1 \%$; furthermore, the majority i.e. $65 \%$ of AMD cases occurred in women (https:// nei.nih.gov/eyedata/amd). Changes in the cellular epigenetic pattern (epimutations) can also be important in the pathogenesis of AMD (Blasiak et al., 2013b). Oxidative stress, protein aggregation and inflammation along with genetic risk factors, are all claimed to be involved in AMD pathogenesis (Kauppinen et al., 2016). Drusen, small yellowish objects containing damaged material, are a characteristic feature of the disease and their presence is a clinical hallmark of AMD. 


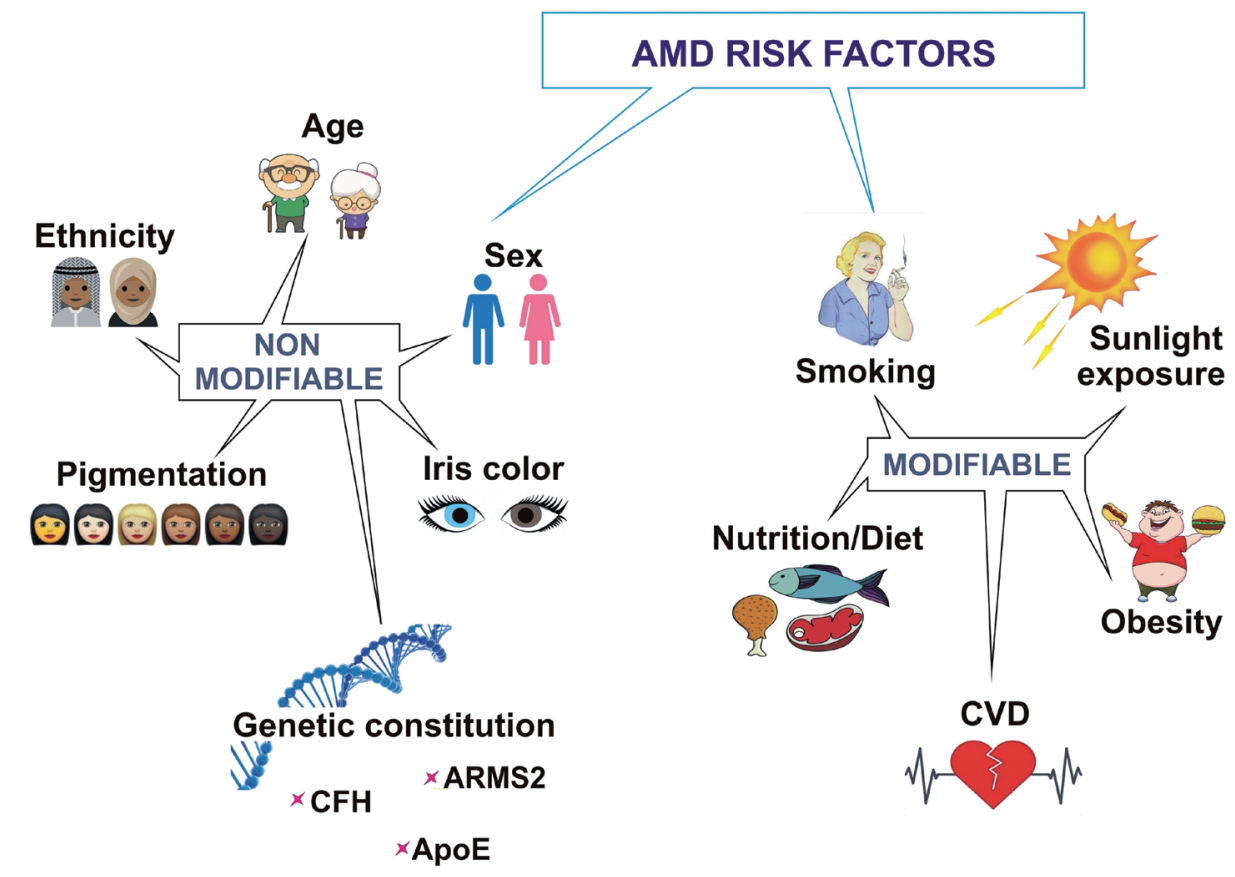

Figure 1. Age-related macular degeneration (AMD) risk factors.

AMD is a multifactorial disease with several genetic and environmental factors important for its pathogenesis. Advanced age, Caucasian ethnicity, female sex, light skin pigmentation, blue iris, fat-rich diet, smoking, UV and blue light exposure, as well as obesity and cardiovascular complications are some commonly accepted AMD risk factors. Mutations in the CFH (complement factor H), ARMS2 (age-related maculopathy susceptibility 2), ApoE (apolipoprotein E) genes are associated with AMD occurrence. CVD - cardiovascular diseases.

Progression of AMD leads to a massive macular degeneration accompanied by dysfunctional retinal pigment epithelium (RPE) cells and photoreceptors, which may die in the end stage of the disease. The death of the retinal cells in AMD is likely executed by apoptotic, pyroptotic or necroptotic program, but it is not known whether any one of these mechanisms predominates in the AMD pathology (Kaarniranta et al., 2017).

\section{Vitamin D}

Vitamin D is claimed to possess a protective potential in many human diseases, including various cancers, cardiovascular disease, diseases of bones, kidney and muscles, hypertension, type 2 diabetes mellitus and others (Ahn et al., 2016; Al Mheid \& Quyyumi, 2017; Duque et al., 2017; Ekmekcioglu et al., 2017; Field et al., 2013; Gaksch et al., 2017; Grubler et al., 2017; Heaney, 2008; Hill \& Aspray, 2017). It seems to have attracted attention in disease prevention due to its key role as a nutritional factor (Sharma et al., 2017).

1,25-Dihydroxyvitamin D [calcitriol, 1,25(OH)2D] is the active form of vitamin $\mathrm{D}$, which binds to its receptor (the vitamin D receptor, VDR) to activate expression of specific genes (Haussler et al., 2013). In humans, inactive vitamin $\mathrm{D}$ is converted into 25 -hydroxyvitamin $\mathrm{D}$ [calcidiol, calcifediol, 25(OH)D] in the liver by CYP2R1 (cytochrome P450 family 2 subfamily $\mathrm{R}$ member 1 ) and then hydroxylated to $1,25(\mathrm{OH}) 2 \mathrm{D}$ in the kidney by $1-\alpha$-hydroxylase (CYP27B1). This final step of pro-vitamin $\mathrm{D}$ activation is upregulated by the parathyroid hormone (PTH).

Synthesis of vitamin D in the skin requires UV radiation, which can induce DNA damage, preferentially cyclobutane pyrimidine dimers and (6-4)-pyrimidine-pyrimidone photoproducts, which are found in many skin cancers, including melanoma (reviewed in (Pawlowska et al., 2016). Vitamin D protects the skin against UV-induced aging and damage in many pathways that may save it from UV-induced DNA damage and the resulting skin cancer (reviewed in: Piotrowska et al., 2016).

Major functions of the products of genes targeted by $1,25(\mathrm{OH}) 2 \mathrm{D}$ are the absorption of dietary calcium and phosphorus and bone mineralization. Therefore, $1,25(\mathrm{OH}) 2 \mathrm{D}$ is intimately involved in the calcium metabolism. Osteoporosis is likely the most distinctive example of a vitamin D age-related pathology (Gallagher, 2013; Hill \& Aspray, 2017; Hill et al., 2013). This inspired us to evaluate the potential of $1,25(\mathrm{OH}) 2 \mathrm{D}$ to slow down or stop the process of aging, or even to reverse it. This issue is closely linked with the role of vitamin D in the pathogenesis and treatment of age-related diseases. The vitamin D receptor is expressed in human retinal pigment epithelium cells as evidenced for ARPE-19 cells (Alsalem et al., 2014). It will be demonstrated that AMD and vitamin D share some common features, e.g. both are associated with aging and the immune system.

\section{VITAMIN D AND AGE-RELATED MACULAR DEGENERATION}

\section{Epidemiology}

No specific association was found between vitamin D deficiency and AMD in a population of elderly subjects living in Bordeaux, France (Cougnard-Gregoire et al., 2015). Similar results were obtained in a population of Israeli individuals aged over 60 years (Golan et al., 2011). No causal association between vitamin D and early, late and neovascular AMD were observed in a populationbased, cross-sectional study enrolling individuals from 7 European countries (McKay et al., 2017). That study also detected no association between $1,25(\mathrm{OH}) 2 \mathrm{D}$ serum levels and polymorphisms in the genes involved in vitamin 
D metabolism, including glucocorticoid genes, VDR, CYP2R1 and CYP27B1, and the occurrence of those three forms in AMD. There was no association between vitamin D status and early AMD in the recently published results of the Atherosclerosis Risk in Communities (ARIC), a cross-sectional study enrolling nearly 8,000 Caucasians and 2000 African Americans (Millen et al., 2017).

One large-scale meta-analysis observed a positive correlation between new AMD cases and vitamin D deficiency (Day et al., 2012). As the authors emphasized, this was the first study analyzing the incidence, not the prevalence, of AMD in a vitamin D association study. There is one interesting investigation which examined the association between AMD and vitamin D, i.e. a lower dietary intake of the vitamin was observed in twins with severe AMD than in monozygotic co-twins with less severe AMD (Seddon et al., 2011). That study had an excellent experimental design and revealed an important finding, i.e. vitamin $\mathrm{D}$ deficiency might be more strictly associated with the later phases of the disease, when it is especially devastating, rather than with its occurrence. However, vitamin $\mathrm{D}$ was not the only factor behind the clinical discordance, since smoking, betaine and methionine intake also contributed to the observed differences. The next important piece of information emerging from that trial is that not only the genetic characteristics, but also the epigenetic profile seems to be important in the development of AMD. However, there were too few subjects enrolled in the trial to permit the elucidation of epigenetic mechanisms in AMD pathogenesis (Blasiak et al., 2013b; Hjelmeland, 2011; Hutchinson et al., 2014; Katoh, 2013; Kwa \& Thrimawithana, 2014; Liu et al., 2012). Somewhat in line with that study are results pointing to a lower mean level of $25(\mathrm{OH}) \mathrm{D}$ in neovascular AMD than in its non-neovascular counterpart (Itty et al., 2014).

Only a few studies have addressed the anatomical relationships between the changes occurring in the retina in AMD and their association with vitamin $\mathrm{D}$ status. It was noted that vitamin $\mathrm{D}$ deficiency in older subjects with no clinical signs of AMD was associated with a reduced macular thickness (Graffe et al., 2012). The results of that study may be important from the perspective of AMD diagnosis in its early, preclinical stage. A lower serum concentration of $25(\mathrm{OH}) \mathrm{D}$ was observed in wet AMD patients with subretinal fibrosis, suggesting that the vitamin D status could be related to the phenotypical diversity of AMD (Singh, 2014). A trial conducted on a group of older French individuals revealed that a vitamin $\mathrm{D}$ deficiency in AMD patients, measured as the $25(\mathrm{OH})$ $\mathrm{D}$ serum concentration, was associated with a decreased thickness of the ganglion cell complex (GCC).

It has been postulated that the effect of vitamin $\mathrm{D}$ in the eye might depend on which region is affected by a particular disease (Uro et al., 2015). Furthermore, it has been proposed that the association between serum levels of $25(\mathrm{OH}) \mathrm{D}$ might depend on sex, which in turn could be due to differences in the sunlight exposure resulting from different behaviors (Kim et al., 2014). It has been speculated that the $25(\mathrm{OH}) \mathrm{D}$ levels could act preventively in late AMD and a similar effect was suspected in diabetic retinopathy, although it seems less likely in case of the dry eye syndrome and cataract.

In a meta-analysis, serum $25(\mathrm{OH}) \mathrm{D}$ concentrations below $50 \mathrm{nmol} / \mathrm{L}$ were claimed to be associated with late AMD, and conversely, high concentrations were considered to confer protection against AMD (Annweiler et al., 2016). However, there is no consensus about which con- centration of vitamin $\mathrm{D}$ in the serum can be considered as "normal" and "lower/higher". Moreover, as mentioned, it is not only $25(\mathrm{OH}) \mathrm{D}$ in the serum which is important, the intracellular 1,25(OH)2D concentrations should also be taken into account when examining the relationship between vitamin $\mathrm{D}$ and the disease.

It has been suggested that high serum concentrations of $25(\mathrm{OH}) \mathrm{D}$ can confer protection against early AMD in individuals aged less than 75 years in a population of postmenopausal women (the Carotenoids in Age-Related Eye Disease Study, CAREDS) (Millen et al., 2011). Interestingly, it was documented that vitamin $\mathrm{D}$ exerted a protective effect to UV irradiation against neovascular AMD in 481 sibling pairs (Morrison et al., 2011). The serum $25(\mathrm{OH}) \mathrm{D}$ concentrations were slightly higher in unaffected individuals than in their AMD-affected counterparts, although that difference was not statistically significant. An evaluation of the metabolome of neovascular AMD patients revealed several unique features as compared to their age-matched controls, including alterations in vitamin D-related metabolites (Osborn et al., 2013).

In summary, some large population-based studies have reported a beneficial effect of vitamin D in AMD prevention, but others have not detected any benefits. It seems that many factors, including ethnicity, dietary habits, genotypes with elevated susceptibility for AMD, and coexisting diseases could be confounding factors.

\section{Diet}

There is no consensus about whether there should be dietary recommendations as a way to prevent AMD or to slow down its progression. In general, it seems that early AMD can be accelerated by the intake of fat-rich foods (mono-, trans- or polyunsaturated fatty acids) (Seddon et al., 2003; Seddon et al., 2011) and reduced by a low intake of saturated fat, fish and nuts (Cugati et al., 2007; Wang et al., 2007). The initial large-scale study on how dietary risk factors could influence AMD was conducted in the first National Health and Nutrition Examination Survey (NHANES), which suggested that a diet rich in fruits and vegetables, and its supplementation with vitamins, could reduce the risk of AMD (Goldberg et al., 1988). The conclusion emerging from the third NHANES was that vitamin D might protect against AMD (Parekh et al., 2007). A small-scale population study on AMD in Japan showed that low intakes of $\mathrm{n}-3$ fatty acids, $\alpha$-tocopherol, zinc, vitamin $\mathrm{D}$, vitamin $\mathrm{C}$, and $\beta$-carotene were associated with an increased risk of developing the neovascular form of the disease (Aoki et al., 2016).

Nutritional risk factors for AMD have been assessed in two large-scale trials: AREDS (Age-Related Eye Disease Study) and AREDS2 (Chew, 2017). AREDS revealed that antioxidant vitamins ( $\mathrm{C}, \mathrm{E}$ and $\beta$-carotene), zinc and the combination of these vitamins with zinc (AREDS formulation, AREDS supplements) substantially reduced the risk of AMD progression to the late stage in a median 6.5 years follow-up study extended to 10 years (Chew et al., 2014). In addition, AREDS proposed some dietary recommendations to slow down the progression of AMD and these have been confirmed in later studies, including those mentioned above. In AREDS2, $\beta$-carotene was replaced with lutein and zeaxanthin, as $\beta$-carotene was suspected to cause lung cancer in former smokers (Chew et al., 2012).

In general, despite certain controversial aspects, the subsequent AREDS2 confirmed a positive effect of some of the dietary compounds reported in the previous 
study and extended it to some diseases coexisting with AMD, including CVD and impaired cognitive functions (Chew et al., 2012; Chew et al., 2014). It is beyond the scope of this review to discuss all of the interesting aspects emerging from the AREDS/AREDS2 studies, especially since they are still providing some new data and evidence.

Large-scale cohort studies associating AMD with the diet are important if we are to understand better the mechanisms of AMD pathogenesis, and in that way to provide the general population with some reliable and relevant nutritional recommendations. Nonetheless, it should be recognized that they are complicated by many confounding factors, which should be carefully controlled in the study design. For example, the tragedy of $\beta$-carotene supplementation and lung cancer shows that not all important aspects of trial design can be anticipated beforehand.

\section{VITAMIN D'S POTENTIAL TO MODULATE AMD RISK FACTORS AND ASSOCIATED STATES}

\section{Aging}

The final step of vitamin $\mathrm{D}$ activation occurs in the kidney (Fig. 2) and this is expected to decrease with age as there is a decline in the general renal function with age (de Jongh et al., 2017; Geraci et al., 2017). It was demonstrated that stimulation with PTH resulted in a substantially reduced production of $1,25(\mathrm{OH}) 2 \mathrm{D}$ in elderly people, in comparison to younger individuals (Kinyamu et al., 1996).

In general, calcium absorption represents the sum of its active transport and passive diffusion (Christakos et al., 2011; Ebeling et al., 1992; Gonzalez Pardo \& Russo de Boland, 2013; Sarma \& Yang, 2011). Calcium absorption declines with age and this decrease can be associated with a disturbed activity of the calcium transport proteins regulated by $1,25(\mathrm{OH}) 2 \mathrm{D}$ (Christakos et al., 2011; Gonzalez Pardo \& Russo de Boland, 2013). Intestinal concentration of VDR can be critical for calcium absorption and a decrease in the numbers of VDRs with age has been observed in humans and experimental animals (de Jongh et al., 2017; Ebeling et al., 1992; Horst et al., 1990; Kinyamu et al., 1996).

1,25-dihydroxyvitamin D also controls an endocrine axis containing the bone-derived hormone FGF23 and the kidney-expressed klotho after association with VDR (Haussler et al., 2012). Such interaction with the involvement of the CYP24A1 and CYP27B1 enzymes, prevents hyperphosphatemia and ectopic calcification, and allows $1,25(\mathrm{OH}) 2 \mathrm{D}$ to maintain mineral integrity of the bones and maintain optimal functions of the kidneys, modulating the aging processes and promoting health span.

The precursor of vitamin $\mathrm{D}$ (cholecalciferol) is mainly produced in the skin and requires exposure to UV light. On the other hand, chronic exposure to sunlight can result in premature skin aging - skin photoaging (Kanaki et al., 2016). It has been demonstrated that the production of pro-vitamin $\mathrm{D}$ in skin explants decreases with age (MacLaughlin \& Holick, 1985). In subsequent studies, it was observed that the vitamin $\mathrm{D}$ endocrine system regulated skin aging and furthermore, not only a deficit, but also an overproduction of vitamin $\mathrm{D}$ could result in premature skin aging (Reichrath, 2012). There are some controversies surrounding the link between skin aging and vitamin $\mathrm{D}$ - there appears to be no correlation be-

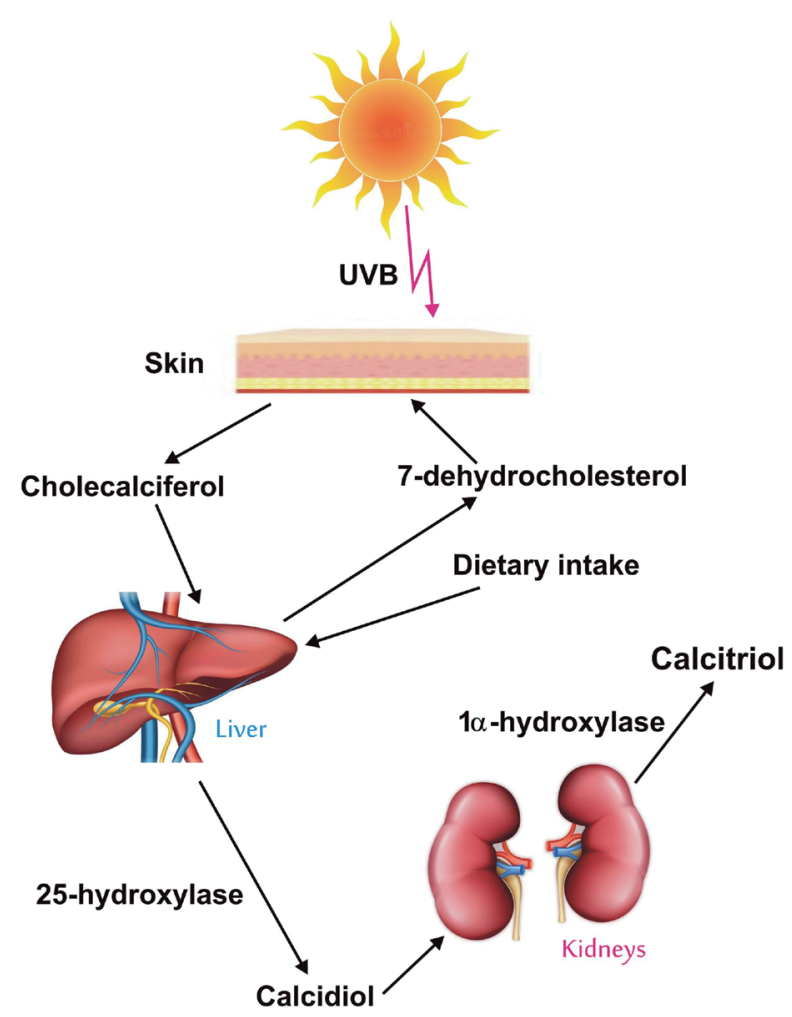

Figure 2. The main steps in the production of active vitamin $D$ that are dependent on aging.

7-dehydrocholesterol, a precursor of vitamin $\mathrm{D}$, is converted to cholecalciferol by solar UVB in the skin. Older people may have an insufficient dietary intake to produce the required amount of 7-dihydrocholesterol and they often suffer from an inadequate exposure to sunlight. Cholecalciferol, which is provitamin D, is converted by liver 25 -hydroxylase to calcidiol (25-hydroxyvitamin D), which is transported to the kidney where it serves as a substrate for calcitriol (1,25-dihydroxyvitamin $D)$ production, requiring the involvement of 1a-hydroxylase. This stage is affected by aging as renal function declines in the elderly. The conversion of calcidiol into calcitriol is regulated by the parathyroid hormone, and the activity of this hormone in older people is lower than in the younger population. Calcitriol can be deactivated by sequential C-25 hydroxylation and C-24 ketonization.

tween the serum $25(\mathrm{OH}) \mathrm{D}$ concentration and facial skin aging (Dawoud et al., 2016).

Another problem associated with vitamin D metabolism in aging is its deficiency due to either insufficient dietary supply and/or lack of enough exposure to sunlight, both of which are common in the elderly (Need et al., 2008).

In summary, the conversion of vitamin $\mathrm{D}$ into its active forms and its role in the cell and organism homeostasis strongly depends on aging (Fig. 2). The disturbance in vitamin D homeostasis in the aging organism raises questions about its role in the pathogenesis of agerelated diseases.

\section{Susceptibility genes}

Mutations in the genes of the complement system are the most significant genetic factors in the pathogenesis of AMD. It has been demonstrated that two risk alleles for the CFH and CFI genotypes can act synergistically with the vitamin $\mathrm{D}$ status, as measured by the serum 25(OH)D levels (Millen et al., 2015; Millen et al., 2011). However, the authors emphasized that they had a relatively small sample size and concluded that the results could be due to chance or residual confounding. 
AMD genetic risk factors include variations in the sequence (mutations) and expression of the HTRA1 (high temperature requirement protein A1) gene located in the 10 q26 chromosomal region, which has many single nucleotide polymorphisms (SNPs), creating haplotypes with high susceptibility to AMD (Liao et al., 2017). A reduced expression of HTRA1 has been associated with drusen formation (Pahl et al., 2013). That study was performed on the 10q26-orthologue region of rhesus monkeys; it revealed that the promoter of the HTRA1 gene contained 9 binding sites for the vitamin D-dependent transcription factor VDR. One of these sites was inactivated by an allele of an SNP present in the HTRA1 promoter, which was associated with drusen formation. An in vitro assay revealed that the drusen risk allele decreased the activity of the HTRA1 promoter after stimulation with $1,25(\mathrm{OH}) 2 \mathrm{D}$, which was apparently at odds with previously published results. Therefore, not only an increase in the expression of the HTRA1 gene, but also an imbalance in its expression can be associated with an increased risk for developing the AMD drusen phenotype.

The evidence for an association between variations in the AMD susceptibility genes and vitamin D status would be more convincing if a concomitant functional study of the variant of the investigated gene had been performed, as in the studies described above. Moreover, it should be taken into account that expression of a single gene results from interaction of many other gene products.

\section{Inflammation}

NLRP3 [NLR (neural retina leucine zipper) family pyrin domain containing 3, NALP3, cryopyrin] is a component of the inflammasome and an important element of the innate immune system. It activates caspase- 1 and this leads to subsequent release of interleukin- $1 \alpha$ (IL-1 $\alpha$ ) and IL-18 (He et al., 2016). It is activated by different stimuli, including various pathogens and products of stressed, damaged or dying cells. NLRP3 activation has been associated with pathogenesis of AMD and its role has been linked with autophagy (Celkova et al., 2015; Kauppinen et al., 2016). It was reported that both, 1,25(OH)2D and $25(\mathrm{OH}) \mathrm{D}$ had increased the release of IL- $1 \alpha$ from human monocytes with this effect being dependent on caspase-1 and NLRP3 (Tulk et al., 2015).

Vitamin D can exert differential effects on the production of pro- and anti-inflammatory cytokines, for example, this vitamin inhibited the release of tumor necrosis factor- $\alpha$ (TNF- $\alpha$ ), interleukin-2 (IL-2) and IL-12, as well as interferon- $\gamma$ (IFN- $\gamma$ ), while it exerted a stimulatory effect on the release of anti-inflammatory cytokines, including IL-4, IL-10 and transforming growth factor- $\beta$ (TGF- $\beta$ ) (Penna \& Adorini, 2000). These and other studies suggest that vitamin $\mathrm{D}$ can be considered as an anti-inflammatory agent. Treatment with $1,25(\mathrm{OH}) 2 \mathrm{D}$ has been shown to reduce the corneal inflammatory response to bacterial infection (Kernacki \& Berk, 1994).

It was shown that 6 weeks' administration of vitamin $\mathrm{D}$ in 12-month aged mice significantly improved indicators of retinal inflammation and aging (Lee et al., 2012). A reduction in amyloid beta accumulation and a decline in the population of retinal macrophages were observed, and these changes correlated with improvements in the animals' visual functions. Therefore, that study provided more evidence of the $\mathrm{D}$ potential to protect against the changes associated with AMD and AD.

Emerging evidence suggests that vitamin D is an important regulator of the immune system (see (Wu et al.,
2018) for review). However, the exact mechanism of that regulation is not completely known. Vitamin Dmetabolizing enzymes and VDR are present in various immunological cells including including monocytes, B and $\mathrm{T}$ cells, antigen-presenting cells and others (Prietl et al., 2013). Vitamin D was reported to stimulate differentiation of immune cells, decrease expression of proinflammatory Th1 (IL2, interferon $\gamma, \mathrm{TNF} \alpha$ ), but increase antinflammatory Th2 (IL3-5, 10) cytokines (Prietl et al., 2013). It also supports the production of antimicrobial peptides with a decrease in antibody production (Reichrath et al., 2016).

\section{Angiogenesis}

Angiogenesis plays a crucial role in the pathogenesis of neovascular AMD; angiogenesis is the formation of new vessels which determines the disease phenotype. This process can be considered as inflammatory angiogenesis, which in contrast to its cancer counterpart, is not a single-cell derived event. However, some results point to the presence of a cross-talk between inflammatory responses at the cellular and molecular levels.

Several studies have highlighted the antiangiogenic potential of vitamin D. Suzuki and coworkers (Suzuki et al., 2000) reported that topical administration of $1,25(\mathrm{OH}) 2 \mathrm{D}$ in mice inhibited corneal neovascularization. These results were confirmed in an in vitro experiment using human corneal epithelial cells, suggesting that this vitamin can inhibit production of various cytokines, including IL-1, granulocyte-macrophage colony-stimulating factor, and TNF- $\alpha$, which can stimulate migration of the Langerhans cells (Suzuki et al., 2000).

Treatment with vitamin $\mathrm{D}$ has been also shown to reduce retinal neovascularization in mice with oxygeninduced retinopathy (Albert et al., 2007). These studies revealed that $1,25(\mathrm{OH}) 2 \mathrm{D}$ inhibited morphogenesis in capillary endothelial cells without affecting their migration or proliferation. However, there is one previous report that vitamin D could inhibit migration of endothelial cells (Hisa et al., 1996). Although mechanisms underpinning the neovascularization encountered in cancer and retinopathies need not be identical, there may be some common pathways e.g. it has been suggested that $1,25(\mathrm{OH}) 2 \mathrm{D}$ could inhibit expression of Bcl-2 in retinoblastoma and endothelial cells (Nebbioso et al., 2017; Shokravi et al., 1995).

\section{Retinal cell death}

Cell death in the retina occurs in the final stages of several eye disorders, including AMD. However, it is not completely clear how these cells die in AMD (Kaarniranta et al., 2017). In general, retinal cells in AMD can undergo apoptosis or necrosis and furthermore apoptosis can be executed in either a caspase-dependent or an independent pathway (Ferrington et al., 2006). It seems that since several different kinds of cells are present in AMD, i.e. RPE cells, choriocapillaries and neurons, various modes of cell death can occur at any given time, and although it has been extensively investigated, the problem of cell death in AMD is still unresolved.

The basic debate centers on the kind of cell death in AMD, i.e. is it a programmed death or necrosis? As stated above, pure necrosis is rather unlikely as the mechanism of cell death, and instead its programmed version, necroptosis, seems more plausible (Blasiak et al., 2017). Similarly, not only apoptosis, but also a version of apoptosis dependent on caspase-1, designated as pyroptosis, may be involved, especially since this pathway is related 
to inflammation (Bergsbaken et al., 2009; Brandstetter et al., 2016). We have proposed that autophagy could be decisive in the choice of cell death mode in AMD (Kaarniranta et al., 2017). In order to assess the protective potential of vitamin D in AMD, its influence on apoptosis, pyroptosis and necroptosis should be explored.

In view of vitamin D's immunoregulatory and antiinflammatory properties, in general it can be considered as a pro-survival molecule (Chirumbolo et al., 2017). This is due to its role in the stress response mediated through calcium oscillatory signaling to induce autophagy or apoptosis via its modulatory activity to combat calcium overload (Chirumbolo et al., 2017; Wilson et al., 2011). Therefore, because it possesses immunoregulatory properties, vitamin D could induce autophagy instead of a programmed death in AMD-associated stress conditions, and in this way perhaps postpone the induction, or slow down progression of AMD. Vitamin D has been reported to protect human islet cells from apoptosis induced by cytokines through upregulation of A20, which is a zinc finger anti-apoptotic protein (Riachy et al., 2002).

It was shown that administration of a cholecalciferol cholesterol emulsion, a precursor of $1,25(\mathrm{OH}) 2 \mathrm{D}$, suppressed pyroptosis signaling in an animal experimental model of colitis where infected macrophages were reported to trigger apoptosis (Xiong et al., 2016). If the activity of caspase- 8 was inhibited, apoptosis was switched to necroptosis through vitamin $\mathrm{D}$ regulation with interconnections to TNF- $\alpha$ and type I IFN (Xu et al., 2014). Therefore, vitamin $\mathrm{D}$ can be considered as a compound capable of modulating programmed cell death, justifying its use in research in AMD prevention and therapy.

\section{DNA damage response}

Oxidative stress is considered as a primary risk factor for AMD, as well as being involved in conditions encountered in RPE cells associated with AMD as a consequence of exposure to other primary risk factors, e.g. tobacco smoking, consumption of a diet rich in polyunsaturated fatty acids, etc. (Blasiak et al., 2014). This kind of stress is associated with an overproduction of reactive oxygen species (ROS) which are capable of damaging cellular macromolecules, including DNA (Jarrett \& Boulton, 2012). Damage to both mitochondrial and nuclear DNA has been considered to play a role in pathogenesis of AMD (Blasiak \& Szaflik, 2011; Blasiak et al., 2013a; Ferrington et al., 2016). We and others have demonstrated that AMD patients displayed more evidence of DNA damage and impaired DNA repair, as compared to control individuals without vision disturbances (Hyttinen et al., 2017; Szaflik et al., 2009). There may be changes in the DNA repair capabilities in AMD patients due to mutations in DNA repair genes (Blasiak et al., 2012; Synowiec et al., 2012). However, it is not known whether the increased levels of DNA damage in AMD patients are the reasons or consequences of the disease since both are possible.

DNA damage induces a cascade of events leading to its repair, tolerance or cell death; this is collectively known as the DNA damage response (DDR) (Zhou \& Elledge, 2000). Consequently, a difference in the extent of DNA damage between two cells can result not only from a difference in DNA-damaging factors, but also from the cellular reaction to either factor. An increased level of DNA damage in the cell can lead to genomic instability, a characteristic finding in many human disorders. Therefore, integrity of DNA and fidelity of its repair mechanisms are important in AMD prevention and

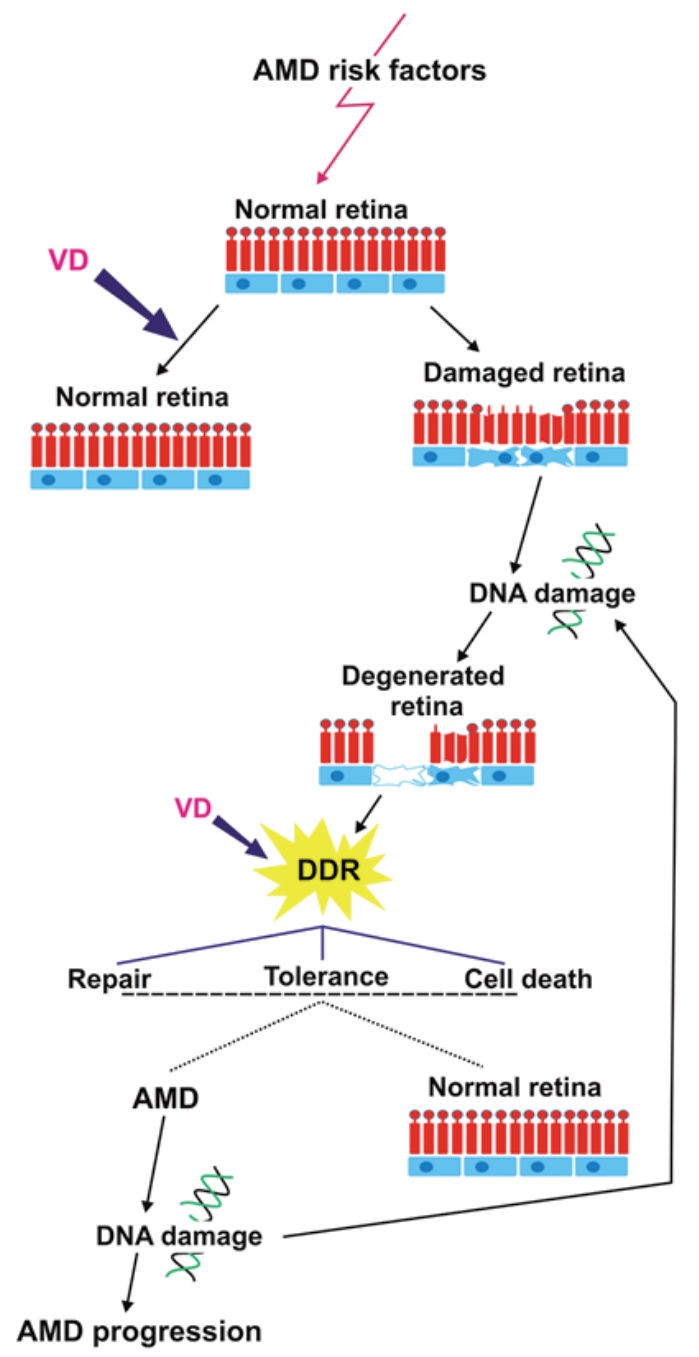

Figure 3. Possible role of vitamin D (VD) in conferring protection against AMD through modulation of DNA damage and DNA damage response (DDR).

Various AMD risk factors can damage both, the nuclear and mitochondrial DNA and these can lead to retinal degeneration. Vitamin $D$ can protect against DNA damage through inactivation of a DNA-damaging factor. DNA damage induces the DNA damage response (DDR), which is a multipathway cellular reaction including many participants, which can be broadly divided into DNA damage repair, its tolerance and cell death. Vitamin D can modulate some of these pathways and thus helps to prevent AMD. However, if $A M D$ has been initiated, then vitamin $D$ may potentiate the existing DNA damage through various mechanisms, including an increase in oxidative stress, a typical occurrence in AMD. This will lead to the accumulation of damaged DNA and hence to AMD progression.

the potential of vitamin D to modulate DDR could also play a role in its properties (Fig. 3).

One of the earliest aspects of DDR is modulation of the cell cycle. $1,25(\mathrm{OH}) 2 \mathrm{D}$ has been shown to increase expression of the p18, p21 and p27 proteins in the head and neck cancer cell line (Gedlicka et al., 2006; Hager et al., 2001; Hager et al., 2004). These proteins are crucial for regulation of the cell cycle and it was observed that the vitamin $\mathrm{D}$ induced cell growth inhibition was due to the induction of G0/G1 arrest and this could be associated with an increased expression of p21 (Gedlicka et al., 2006). This increase could be linked with an elevated expression of $\mathrm{p} 53$, which is a master regulator of the cell cycle (Maguire \& Campbell, 2010) [19]. Another 
study demonstrated that $1,25(\mathrm{OH}) 2 \mathrm{D}$ induced arrest at the G1/S checkpoint in the response to mitogens (Shen \& Ji, 2015). Therefore, regulation of the cell cycle can be an important mechanism of DDR modulation by vitamin D. However, it should be taken into account that in normal adult retina, the cells do not undergo cycling, i.e. they do not replicate. Retinal neurons are post-mitotic cells and RPE cells are G0 quiescent cells. However, when the RPE cells in the central retina are damaged, they can be replaced by their proliferating counterparts from the periphery (Al-Hussaini et al., 2008). Therefore, DDR with cell cycle regulation is essential for the proper functioning of RPE and the replacement of degraded cells, and failures in these processes have been directly associated with a slow progression of AMD to its final stage.

AMD has been associated with a permanent oxidative stress and ROS overproduction in retinal cells. Oxidative modifications of the DNA bases are the main DNA lesions induced by moderate levels of oxidative stress and 8-oxo-2'-deoxyguanosine (8oxoG) is a marker of DNA oxidation. In general, influence of vitamin $\mathrm{D}$ on the level of ROS-induced DNA damage, which is usually evaluated by the level of 8 oxoG, suggests that it possesses a protective effect, but the mechanism underlying this action seems to be dependent on many factors, including the kind of cell/tissue and the underlying cellular conditions, as well as the VDR state (Fedirko et al., 2010; Kallay et al., 2002; Mason et al., 2010).

Vitamin D exerts several other effects on the integrity and stability of DNA; these include the induction of apoptosis, as well as the prevention of DNA double-strand breaks and consequent chromosomal aberrations (Chatterjee, 2001). Therefore, vitamin D has the potential to substantially modulate the DDR, and this property can be included into the repertoire of possible ways in which this vitamin can prevent the occurrence and development of AMD. It should be emphasized that impairment of autophagy, which has been linked with AMD, can be considered as a DDR reaction.

\section{Autophagy}

Autophagy is a mechanism of cellular internal quality control, i.e. damaged or no longer needed cellular components, including organelles, are degraded in vesicles formed by the fusion of autophagy-specific autophagosomes with lysosomes (Mizushima, 2007). Autophagic degradation can also act against invaders, including viruses and bacteria. Autophagy can occur in three distinct forms: microautophagy, macroautophagy, which here will be subsequently simply called autophagy, and chaperonemediated autophagy; many proteins are known to be important in its regulation, including about 30 autophagyrelated proteins (ATGs), e.g. Beclin-1, mechanistic target of rapamycin (mTOR), the serine/threonine kinase 1 (ULK1), FIP-200, p62 (SQSTM1), microtubule-associated protein light chain 3 (LC3) and others (Blasiak et al., 2014).

Impaired autophagy impacts on the functioning of the RPE cells and is recognized as being crucial in the pathogenesis of many human diseases, including AMD (Chang et al., 2015; Li et al., 2015; Mitter et al., 2012). Its precise role in AMD is not fully understood, but dysfunctional autophagy leads to an increased accumulation of protein aggregates in the RPE cells, resulting from damage to cellular proteins by AMD risk factors (reviewed in: Blasiak et al., 2019). This is supported by the involvement of autophagy in the degradation of used photoreceptor outer segments by the RPE cells $\mathrm{Yu}$ et al., 2018). The photoreceptor segment can be also removed by heterophagy and this process takes place on the apical side of RPE cells, associated with photoreceptor layer (Bosch et al., 1993). This supports the key role of RPE cells in AMD pathogenesis. Another mechanism is thought to involve accumulation of lipofuscin, yellowbrown pigment granules, in aging RPE cells, which are cleared in the lysosome (Kaarniranta et al., 2013). Impaired autophagy reduces efficiency of this process and can contribute to accelerated aging as well as potentiating other risk factors, including oxidative stress, which creates a vicious cycle-like state.

Vitamin D and its analogs can induce autophagy in normal and cancer cells via several mechanisms (Wu \& Sun, 2011). Hoyer-Hansen and others (Hoyer-Hansen et al., 2007) demonstrated that autophagy could be induced by an increase in the cytosolic calcium concentration. They also showed that $1,25(\mathrm{OH}) 2 \mathrm{D}$, as well as its chemotherapeutic analog EB 1089, induced an increase in the calcium level and autophagy in the breast cancer MCF-7 cells. Vitamin D analogs inhibited mTOR activity and induced accumulation of autophagosomes in a process dependent on Beclin-1 and ATG7. Other mediators of this process were $\mathrm{Ca}^{2+} /$ calmodulin-dependent kinase kinase- $\beta$ and AMP-activated protein kinase. Furthermore, the effects of these vitamin $\mathrm{D}$ analogs were inhibited by Bcl-2 targeting endoplasmic reticulum.

However, the literature contains conflicting results, suggesting a dual role of calcium ions in autophagy as they can both, stimulate and inhibit this process (Decuypere et al., 2011).

Autophagy is considered as the bridge between the innate and adaptive immunity and vitamin D plays a key role in the immunological response (Shibutani et al., 2015). Consequently, an interrelationship linking this vitamin with autophagy could be observed in a pathogen infection, as such infection can potentially evoke both, the vitamin-D mediated immune response and the triggering of autophagy. For example, human cathelicidin hCAP-18/LL-37, an antimicrobial peptide, was claimed to be a link between vitamin D-dependent immunity and the pathways activated in autophagy (Jee et al., 2016; Yuk \& Jo, 2013).

As mentioned above, vitamin D and its receptor signaling play an important role in inflammatory responses (Mangin et al., 2014). As there seems to be a clear connection between inflammation and autophagy, it can be assumed that vitamin D plays a role in the regulation of inflammation through autophagic mechanisms as is the case in inflammatory bowel disease (Suh et al., 2017). The anti-inflammatory autophagy-mediated actions of vitamin D may involve several mechanisms, including inhibition of $\mathrm{TNF}-\alpha$ with a concomitant decrease in the Beclin-1 level, recruitment of ATG16, inhibition of IFN- $\gamma$.

It has been shown that vitamin $\mathrm{D}$ can trigger autophagic death in human myeloid leukemia cells by stimulating binding of Beclin-1 to class III phosphatidylinositol 3-kinase to induce autophagy (Wang et al., 2008). Vitamin D stimulated phosphorylation of the $\mathrm{BH} 3$ domain in the pro-apoptotic Bad (Bcl-2-associated death promoter) protein, resulting in disassociation of the $\mathrm{Bad} /$ Bcl-xL (B-cell lymphoma-extra large) complex with subsequent inhibition of apoptotic signals. Beclin-1 seems to be critical for these effects, as its knockdown abolished the proautophagic effect of vitamin D.

All of these mechanisms suggest that vitamin D and autophagy can be associated with innate immunity, inflammation, infection and cancer (Wu \& Sun, 2011). 


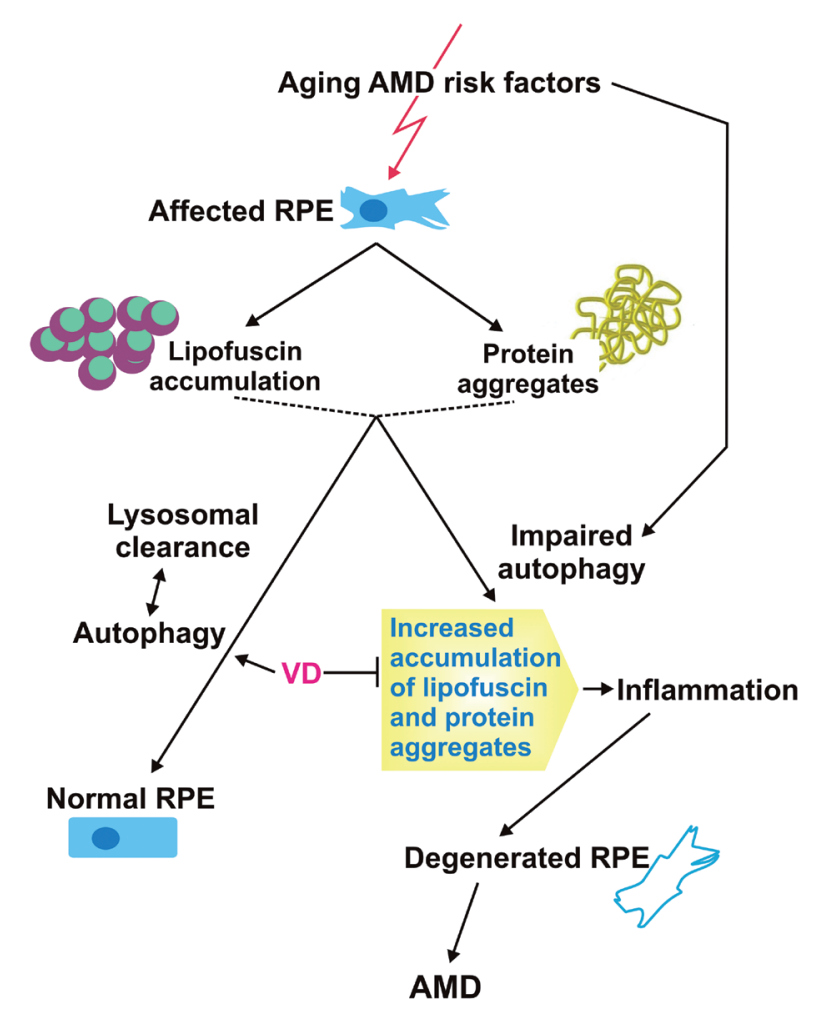

Figure. 4. Autophagy in age-related macular degeneration (AMD) and vitamin D (VD) action.

AMD risk factors, including aging, can induce accumulation of lipofuscin and protein aggregates in retinal pigment epithelium (RPE, represented here by a single RPE cell); these are normally cleared by lysosomal degradation and autophagy, respectively. Autophagy can be impaired by aging and other AMD risk factors, and impaired autophagy can contribute to accelerated aging and potentiate other AMD risk factors, e.g. oxidative stress. Impaired autophagy can also increase accumulation of lipofuscin and protein aggregates, leading to inflammation. Vitamin $D$ has several beneficial properties 1) it can modulate autophagy, 2) it stimulates clearing of lipofuscin and protein aggregates and 3) it directly dampens the inflammatory response

Unfortunately, there is a lack of information relating to vitamin $\mathrm{D}$ and autophagy in the retina - the only published study was conducted in the zebrafish eye/retina which was being exploited as a model of polyglutaminerelated neurodegenerative disorders (Underwood et al., 2010). However, autophagy is a ubiquitous process, i.e. it is not strictly limited to some specific cells or tissues and therefore its modulation by vitamin $\mathrm{D}$ in the eye/ retina is possible. Some of the putative relationships between vitamin $\mathrm{D}$ and autophagy which have originated from work done in cancer cells need to be interpreted with caution before extrapolating those findings to normal cells, since usually the experiments conducted with cancer cells have required high, non-physiological concentrations of this vitamin in order to obtain an antineoplastic effect. Currently, only a putative mechanism of involvement of autophagy in AMD pathogenesis can be considered (Fig. 4).

\section{CONCLUSIONS AND PERSPECTIVES}

It is not easy to answer the question posed in the title of this review, as some results on the protective potential of vitamin $\mathrm{D}$ in AMD are inconsistent or even contradictory. The most convincing evidence supporting the hypothesis that this vitamin exerts a beneficial effect in AMD originates from its abilities to modulate the immune system, as well as its ability to inhibit inflammation and angiogenesis.

There is no consensus about the precise concentration of vitamin $\mathrm{D}$ in the serum, for example, which levels should be considered as "normal" and "lower/higher than normal". However, some kind of consensus seems to be reached and some guidelines can be followed (reviewed in: Pludowski et al., 2013; Pludowski et al., 2018). Still, these guidelines focus mainly on particular aspects on vitamin D metabolism. When the role of this vitamin in bone is considered, the optimal recommended level of $25(\mathrm{OH}) \mathrm{D}$ in the serum is $20 \mathrm{ng} / \mathrm{mL}$ with daily doses of 400-800 IU, depending on age. When pleiotropic effects of vitamin $\mathrm{D}$ are considered, a concentration of $30 \mathrm{ng} /$ $\mathrm{mL} 25(\mathrm{OH}) \mathrm{D}$ and daily doses 400-2000 IU are recommended, depending on age, BMI, health status and ethnicity.

According to various sources, including the Vitamin D Council, the Endocrine Society and the Institute of Medicine, the same concentration of $25(\mathrm{OH}) \mathrm{D}$ in the serum can be considered as either a sufficient or a deficient level of the vitamin (Mangin et al., 2014). Therefore, the cut-off value for sufficiency and deficiency of $25(\mathrm{OH})$ $\mathrm{D}$ in the serum should be validated by results from experimental and epidemiological research. This is a serious problem, as these results should be adjusted to an "average individual" level. Autophagy, as a mechanism of cellular action of vitamin D in AMD, seems especially important in the context of this vitamin's preventive potential against AMD, as impaired autophagy has been associated with several critical features of AMD pathogenesis. Impaired autophagy has been implicated in other aspects of AMD pathophysiology, including an impaired DDR and activation of the inflammasome, as autophagy can be involved in both processes (Hyttinen et al., 2017). As vitamin $\mathrm{D}$ can play a role in regulation of inflammation through autophagic mechanisms, as shown for the inflammatory bowel disease, it may be also able to influence AMD through an identical or a similar mechanism. Autophagy can lead to protection of AMD-affected retina cells from cell death, but it could also accelerate their demise, and switching between these two effects could be dependent on many factors. Therefore, interconnections between AMD, autophagy and inflammation in the context of the regulatory role of vitamin $\mathrm{D}$ in inflammation need to be addressed in further research.

Degeneration of the retina is another important issue to be considered in assessing the potential of vitamin $\mathrm{D}$ to modulate AMD. It has been suggested that cellular senescence is a key process contributing to degeneration of retina cells encountered in AMD (Kozlowski, 2015), and we have developed this hypothesis (Blasiak et al., 2017). In the normal adult human eye, the RPE cells of the central retina are quiescent and not able to proliferate due to spatial restrictions. If they are occasionally damaged, they can be replaced by their proliferating counterparts from the periphery (Al-Hussaini et al., 2008). However, if the majority of RPE cells are senescent, the compensating mechanisms can fail and lead to AMD progression. Oxidative stress has been shown to induce senescence in the RPE cells, but the exact mechanism has not been clarified (Aryan et al., 2016). The release of pro-inflammatory cytokines and ROS by senescent cells, DNA damage-induced senescence, induction of senescence in neighboring cells, as well as the interplay between senescence and autophagy are considered to regulate RPE degeneration (Sikora et al., 2014). There- 
fore, it would be interesting to examine whether vitamin $\mathrm{D}$ can modulate senescence in RPE cells or more extensively in other retinal cells.

In conclusion, there are many pathways through which vitamin $\mathrm{D}$ can affect $\mathrm{AMD}$, mainly by modulating effects associated with the disease. Vitamin D has the potential to both, prevent and slow down the progress of AMD, but several issues, including the dose-dependency of this vitamin, its influence on diseases coexisting with AMD, the individual's exposure to sunlight as a factor influencing the activation of this vitamin as well as other risk factors in AMD, need to be addressed before drawing any definite conclusions about the protective role of vitamin $\mathrm{D}$ in $\mathrm{AMD}$. It is essential that there should be a resolution of these unanswered questions before it will be possible to issue any dietary recommendations about the dose of vitamin $\mathrm{D}$ to be taken by AMD patients.

\section{Acknowledgments}

We thank Ewen MacDonald for language editing and Monika Kicinska for her help in figures' preparation.

\section{Conflicts of Interest}

The authors declare no conflict of interest.

\section{REFERENCES}

Ahn J, Park S, Zuniga B, Bera A, Song CS, Chatterjee B (2016) Vitamin D in prostate cancer. Vitam Horm 100: 321-355. https://doi. org/10.1016/bs.vh.2015.10.012

Al-Hussaini H, Kam JH, Vugler A, Semo M, Jeffery G (2008) Mature retinal pigment epithelium cells are retained in the cell cycle and proliferate in vivo. Mol Vis 14: 1784-1791

Al Mheid I, Quyyumi AA (2017) Vitamin D and cardiovascular disease: Controversy unresolved. I Am Coll Cardiol 70: 89-100. https://doi. org/10.1016/j.jacc.2017.05.031

Albert DM, Scheef EA, Wang S, Mehraein F, Darjatmoko SR, Sorenson CM, Sheibani N (2007) Calcitriol is a potent inhibitor of retinal neovascularization. Invest Ophthalmol Vis Sci 48: 2327-2334. https:// doi.org/10.1167/iovs.06-1210

Alsalem JA, Patel D, Susarla R, Coca-Prados M, Bland R, Walker EA, Rauz S, Wallace GR (2014) Characterization of vitamin d production by human ocular barrier cellsvitamin d production by human ocular barrier cells. Invest Ophthalmol Vis Sci 55: 2140-2147. https:// doi.org/10.1167/iovs.13-13019

Annweiler C, Drouet M, Duval GT, Pare PY, Leruez S, Dinomais M, Milea D (2016) Circulating vitamin d concentration and age-related macular degeneration: Systematic review and meta-analysis. Maturitas 88: 101-112. https://doi.org/10.1016/i.maturitas.2016.04.002

Aoki A, Inoue M, Nguyen E, Obata R, Kadonosono K, Shinkai S, Hashimoto H, Sasaki S, Yanagi Y (2016) Dietary n-3 fatty acid, alpha-tocopherol, zinc, vitamin d, vitamin c, and beta-carotene are associated with age-related macular degeneration in japan. Sci Rep 6: 20723. https://doi.org/10.1038/srep20723

Aryan N, Betts-Obregon BS, Perry G, Tsin AT (2016) Oxidative stress induces senescence in cultured rpe cells. Open Neurol J 10: 83-87. https://doi.org/10.2174/1874205x01610010083

Bergsbaken T, Fink SL, Cookson BT (2009) Pyroptosis: Host cell death and inflammation. Nat Rev Microbiol 7: 99-109. https://doi. org $/ 10.1038 /$ nrmicro2070

Blasiak J, Szaflik JP (2011) DNA damage and repair in age-related macular degeneration. Front Biosci (Landmark Ed) 16: 1291-1301

Blasiak J, Synowiec E, Salminen A, Kaarniranta K (2012) Genetic variability in DNA repair proteins in age-related macular degeneration. Int J Mol Sci 13: 13378-13397. https://doi.org/10.3390/ ijms131013378

Blasiak J, Glowacki S, Kauppinen A, Kaarniranta K (2013a) Mitochondrial and nuclear DNA damage and repair in age-related macular degeneration. Int J Mol Sci 14: 2996-3010. https://doi.org/10.3390/ ijms14022996

Blasiak J, Salminen A, Kaarniranta K (2013b) Potential of epigenetic mechanisms in amd pathology. Front Biosci (Schol Ed) 5: 412-425

Blasiak J, Petrovski G, Vereb Z, Facsko A, Kaarniranta K (2014) Oxidative stress, hypoxia, and autophagy in the neovascular processes of age-related macular degeneration. Biomed Res Int 2014: 768026. https://doi.org/10.1155/2014/768026

Blasiak J, Piechota M, Pawlowska E, Szatkowska M, Sikora E, Kaarniranta K (2017) Cellular senescence in age-related macu- lar degeneration: Can autophagy and DNA damage response play a role? Oxid Med Cell Longev 2017: 5293258. https://doi. org/10.1155/2017/5293258

Blasiak J, Pawlowska E, Szczepanska J, Kaarniranta K (2019) Interplay between autophagy and the ubiquitin-proteasome system and its role in the pathogenesis of age-related macular degeneration. Int $J$ Mol Sci 20. https://doi.org/10.3390/ijms20010210

Bosch E, Horwitz J, Bok D (1993) Phagocytosis of outer segments by retinal pigment epithelium: Phagosome-lysosome interaction. J Histochem Cytochem 41: 253-263. https://doi.org/10.1177/41.2.8419462

Brandstetter C, Patt J, Holz FG, Krohne TU (2016) Inflammasome priming increases retinal pigment epithelial cell susceptibility to lipofuscin phototoxicity by changing the cell death mechanism from apoptosis to pyroptosis. J Photochem Photobiol B 161: 177-183. https:// doi.org/10.1016/j.jphotobiol.2016.05.018

Broadhead GK, Grigg JR, Chang AA, McCluskey P (2015) Dietary modification and supplementation for the treatment of agerelated macular degeneration. Nutr Rev 73: 448-462. https://doi. org/10.1093/nutrit/nuv005

Celkova L, Doyle SL, Campbell M (2015) Nlrp3 inflammasome and pathobiology in amd. J Clin Med 4: 172-192. https://doi. org/10.3390/jcm4010172

Chang YC, Hsieh MC, Wu HJ, Wu WC, Kao YH (2015) Methylglyoxal, a reactive glucose metabolite, enhances autophagy flux and suppresses proliferation of human retinal pigment epithelial arpe19 cells. Toxicol In Vitro 29: 1358-1368. https://doi.org/10.1016/j. tiv.2015.05.014

Chatterjee M (2001) Vitamin d and genomic stability. Mutat Res 475 : 69-87

Chew EY (2017) Nutrition, genes, and age-related macular degeneration: What have we learned from the trials? Ophthalmologica 238: 1-5. https://doi.org/10.1159/000473865

Chew EY, Clemons T, SanGiovanni JP, Danis R, Domalpally A, McBee W, Sperduto R, Ferris FL (2012) The age-related eye disease study 2 (areds2): Study design and baseline characteristics (areds2 report number 1). Ophthalmology 119: 2282-2289. https://doi. org/10.1016/j.ophtha.2012.05.027

Chew EY, Clemons TE, Agron E, Sperduto RD, Sangiovanni JP, Davis MD, Ferris FL, 3rd (2014) Ten-year follow-up of age-related macular degeneration in the age-related eye disease study: Areds report no. 36. JAMA Ophthalmol 132: 272-277. https://doi.org/10.1001/ jamaophthalmol.2013.6636

Chirumbolo S, Bjorklund G, Sboarina A, Vella A (2017) The role of vitamin $\mathrm{d}$ in the immune system as a pro-survival molecule. Clin Ther 39: 894-916. https://doi.org/10.1016/j.clinthera.2017.03.021

Christakos S, Dhawan P, Porta A, Mady LJ, Seth T (2011) Vitamin $\mathrm{d}$ and intestinal calcium absorption. Mol Cell Endocrinol 347: 25-29. doi:10.1016/j.mce.2011.05.038

Cougnard-Gregoire A, Merle BM, Korobelnik JF, Rougier MB, Delyfer MN, Feart C, Le Goff M, Dartigues JF, Barberger-Gateau P, Delcourt C (2015) Vitamin d deficiency in community-dwelling elderly is not associated with age-related macular degeneration. J Nutr 145: 1865-1872. https://doi.org/10.3945/jn.115.214387

Cugati S, Cumming RG, Smith W, Burlutsky G, Mitchell P, Wang JJ (2007) Visual impairment, age-related macular degeneration, cataract, and long-term mortality: The blue mountains eye study. Arch Ophthalmol 125: 917-924. https://doi.org/10.1001/archopht.125.7.917

Dawoud NM, Bakry OA, Shoeib MA, Ismael HN (2016) Serum vitamin D and facial aging: Is there a link? Skin Pharmacol Physiol 29: 76-82. https://doi.org/10.1159/000443839

Day S, Acquah K, Platt A, Lee PP, Mruthyunjaya P, Sloan FA (2012) Association of vitamin d deficiency and age-related macular degeneration in medicare beneficiaries. Arch Ophthalmol 130: 1070-1071. https://doi.org/10.1001/archophthalmol.2012.439

de Jongh RT, van Schoor NM, Lips P (2017) Changes in vitamin d endocrinology during aging in adults. Mol Cell Endocrinol. https:// doi.org/10.1016/i.mce.2017.06.005

Decuypere JP, Bultynck G, Parys JB (2011) A dual role for ca(2+) in autophagy regulation. Cell Calcium 50: 242-250. https://doi. org/10.1016/j.ceca.2011.04.001

Duque G, Daly RM, Sanders K, Kiel DP (2017) Vitamin D, bones and muscle: Myth versus reality. Australas J Ageing 36 (Suppl 1): 8-13. https://doi.org/10.1111/ajag.12408

Ebeling PR, Sandgren ME, DiMagno EP, Lane AW, DeLuca HF, Riggs BL (1992) Evidence of an age-related decrease in intestinal responsiveness to vitamin D: Relationship between serum 1,25-dihydroxyvitamin $\mathrm{d} 3$ and intestinal vitamin $\mathrm{d}$ receptor concentrations in normal women. J Clin Endocrinol Metab 75: 176-182. https://doi. org/10.1210/jcem.75.1.1320048

Ekmekcioglu C, Haluza D, Kundi M (2017) 25-hydroxyvitamin d status and risk for colorectal cancer and type 2 diabetes mellitus: A systematic review and meta-analysis of epidemiological studies. Int J Environ Res Public Health 14. https://doi.org/10.3390/ijerph14020127

Everitt AV, Hilmer SN, Brand-Miller JC, Jamieson HA, Truswell AS, Sharma AP, Mason RS, Morris BJ, Le Couteur DG (2006) Dietary approaches that delay age-related diseases. Clin Interv Aging 1: 11-31. 
Fedirko V, Bostick RM, Long Q, Flanders WD, McCullough ML, Sidelnikov E, Daniel CR, Rutherford RE, Shaukat A (2010) Effects of supplemental vitamin $d$ and calcium on oxidative DNA damage marker in normal colorectal mucosa: A randomized clinical trial. Cancer Epidemiol Biomarkers Prev 19: 280-291. https://doi. org/10.1158/1055-9965.epi-09-0448

Ferrington DA, Kapphahn RJ, Leary MM, Atilano SR, Terluk MR, Karunadharma P, Chen GK, Ratnapriya R, Swaroop A, Montezuma SR, Kenney MC (2016) Increased retinal mtdna damage in the cfh variant associated with age-related macular degeneration. Exp Eye Res 145: 269-277. https://doi.org/10.1016/j.exer.2016.01.018

Ferrington DA, Tran TN, Lew KL, Van Remmen H, Gregerson DS (2006) Different death stimuli evoke apoptosis via multiple pathways in retinal pigment epithelial cells. Exp Eye Res 83: 638-650. https:// doi.org/10.1016/j.exer.2006.03.003

Field S, Davies J, Bishop DT, Newton-Bishop JA (2013) Vitamin d and melanoma. Dermatoendocrinol 5: 121-129. https://doi.org/10.4161/ derm. 25244

Gaksch M, Jorde R, Grimnes G, Joakimsen R, Schirmer H, Wilsgaard T, Mathiesen EB, Njolstad I, Lochen ML, Marz W, Kleber ME, Tomaschitz A, Grubler M, Eiriksdottir G, Gudmundsson EF, Harris TB, Cotch MF, Aspelund T, Gudnason V, Rutters F, Beulens JW, van 't Riet E, Nijpels G, Dekker JM, Grove-Laugesen D, Rejnmark L, Busch MA, Mensink GB, Scheidt-Nave C, Thamm M, Swart KM, Brouwer IA, Lips P, van Schoor NM, Sempos CT, Durazo-Arvizu RA, Skrabakova Z, Dowling KG, Cashman KD, Kiely M, Pilz S (2017) Vitamin D and mortality: Individual participant data meta-analysis of standardized 25-hydroxyvitamin d in 26916 individuals from a european consortium. PLoS One 12: e0170791. https://doi.org/10.1371/journal.pone.0170791

Gallagher JC (2013) Vitamin d and aging. Endocrinol Metab Clin North Am 42: 319-332. https://doi.org/10.1016/j.ecl.2013.02.004

Gedlicka C, Hager G, Weissenbock M, Gedlicka W, Knerer B, Kornfehl J, Formanek M (2006) 1,25(oh)2vitamin d3 induces elevated expression of the cell cycle inhibitor p18 in a squamous cell carcinoma cell line of the head and neck. J Oral Pathol Med 35: 472-478. https://doi.org/10.1111/j.1600-0714.2006.00407.x

Geraci S, Chacon-Caldera J, Cullen-McEwen LA, Schad LR, Sticht C, Puelles VG, Bertram JF, Gretz N (2017) Combining new tools to assess renal function and morphology: A holistic approach to study the effects of aging and a congenital nephron deficit. $A m J$ Physiol Renal Physiol: ajprenal.00329.02015. https://doi.org/10.1152/ajprenal.00329.2015

Golan S, Shalev V, Treister G, Chodick G, Loewenstein A (2011) Reconsidering the connection between vitamin d levels and agerelated macular degeneration. Eye (Lond) 25: 1122-1129. https://doi. org/10.1038/eye.2011.174

Goldberg J, Flowerdew G, Smith E, Brody JA, Tso MO (1988) Factors associated with age-related macular degeneration. An analysis of data from the first national health and nutrition examination survey. Am J Epidemiol 128: 700-710

Gonzalez Pardo V, Russo de Boland A (2013) Age-related changes in the response of intestinal cells to 1alpha,25(oh)2-vitamin d3. Ageing Res Rev 12: 76-89. https://doi.org/10.1016/j.arr.2012.06.001

Graffe A, Milea D, Annweiler C, Beauchet O, Mauget-Faysse M, Beauchet O, Kodjikian L, Milea D (2012) Association between hypovitaminosis $\mathrm{d}$ and late stages of age-related macular degeneration: A case-control study. J Am Geriatr Soc 60: 1367-1369. https://doi. org/10.1111/j.1532-5415.2012.04015.x

Grubler MR, Marz W, Pilz S, Grammer TB, Trummer C, Mullner C, Schwetz V, Pandis M, Verheyen N, Tomaschitz A, Fiordelisi A, Laudisio D, Cipolletta E, Iaccarino G (2017) Vitamin-D concentrations, cardiovascular risk and events - a review of epidemiological evidence. Rev Endocr Metab Disord 18: 259-272. https://doi. org/10.1007/s11154-017-9417-0

Hager G, Formanek M, Gedlicka C, Thurnher D, Knerer B, Kornfehl $\mathrm{J}$ (2001) 1,25(oh) 2 vitamin $\mathrm{d} 3$ induces elevated expression of the cell cycle-regulating genes p21 and p27 in squamous carcinoma cell lines of the head and neck. Acta Otolaryngol 121: 103-109

Hager G, Kornfehl J, Knerer B, Weigel G, Formanek M (2004) Molecular analysis of p21 promoter activity isolated from squamous carcinoma cell lines of the head and neck under the influence of $1,25(\mathrm{OH}) 2$ vitamin d3 and its analogs. Acta Otolarynol 124: 90-96

Haussler MR, Whitfield GK, Kaneko I, Forster R, Saini R, Hsieh J-C, Haussler CA, Jurutka PW (2012) The role of vitamin d in the fgf 23 , klotho, and phosphate bone-kidney endocrine axis. Rev Endocr Metab Disord 13: 57-69. https://doi.org/10.1007/s11154-011-9199-8

Haussler MR, Whitfield GK, Kaneko I, Haussler CA, Hsieh D, Hsieh JC, Jurutka PW (2013) Molecular mechanisms of vitamin D action. Calcif Tissue Int 92: 77-98. https://doi.org/10.1007/s00223-0129619-0

He Y, Hara H, Nunez G (2016) Mechanism and regulation of NLRP3 inflammasome activation. Trends Biochem Sci 41: 1012-1021. https:// doi.org/10.1016/j.tibs.2016.09.002

Heaney RP (2008) Vitamin d in health and disease. Clin J Am Soc Nephrol 3: 1535-1541. https://doi.org/10.2215/cjn.01160308
Hill TR, Aspray TJ (2017) The role of vitamin d in maintaining bone health in older people. Ther Adv Musculoskelet Dis 9: 89-95. https:// doi.org/10.1177/1759720x17692502

Hill TR, Aspray TJ, Francis RM (2013) Vitamin d and bone health outcomes in older age. Proc Nutr Soc 72: 372-380. https://doi. org/10.1017/s0029665113002036

Hisa T, Taniguchi S, Tsuruta D, Hirachi Y, Ishizuka S, Takigawa M (1996) Vitamin d inhibits endothelial cell migration. Arch Dermatol Res 288: 262-263

Hjelmeland LM (2011) Dark matters in amd genetics: Epigenetics and stochasticity. Invest Ophthalmol Vis Sci 52: 1622-1631. https://doi. org/10.1167/iovs.10-6765

Horst RL, Goff JP, Reinhardt TA (1990) Advancing age results in reduction of intestinal and bone 1,25-dihydroxyvitamin d receptor. Endocrinology 126: 1053-1057. https://doi.org/10.1210/endo-126-21053

Hoyer-Hansen M, Bastholm L, Szyniarowski P, Campanella M, Szabadkai G, Farkas T, Bianchi K, Fehrenbacher N, Elling F, Rizzuto R, Mathiasen IS, Jaattela M (2007) Control of macroautophagy by calcium, calmodulin-dependent kinase kinase-beta, and bcl-2. Mol Cell 25: 193-205. https://doi.org/10.1016/j.molcel.2006.12.009

Hutchinson JN, Fagerness J, Kirby A, Reynolds R, Zak A, Gimelbrant A, Plenge R, Daly M, Chess A, Seddon JM (2014) (epi)genetic analyses of age-related macular degeneration: Case-control and discordant twin studies. Hum Hered 78: 59-72. https://doi. org/10.1159/000362814

Hyttinen JM, Blasiak J, Niittykoski M, Kinnunen K, Kauppinen A, Salminen A, Kaarniranta K (2017) DNA damage response and autophagy in the degeneration of retinal pigment epithelial cells-implications for age-related macular degeneration (amd). Ageing Res Rev 36: 64-77. https://doi.org/10.1016/j.arr.2017.03.006

Itty S, Day S, Lyles KW, Stinnett SS, Vajzovic LM, Mruthyunjaya P (2014) Vitamin d deficiency in neovascular versus nonneovascular age-related macular degeneration. Retina 34: 1779-1786. https://doi. org/10.1097/iae.0000000000000178

Jarrett SG, Boulton ME (2012) Consequences of oxidative stress in age-related macular degeneration. Mol Aspects Med 33: 399-417. https://doi.org/10.1016/j.mam.2012.03.009

Jee D, Kang S, Yuan C, Cho E, Arroyo JG (2016) Serum 25-hydroxyvitamin $\mathrm{d}$ levels and dry eye syndrome: Differential effects of vitamin d on ocular diseases. PLoS One 11: e0149294. https://doi. org/10.1371/journal.pone.0149294

Kaarniranta K, Sinha D, Blasiak J, Kauppinen A, Vereb Z, Salminen A, Boulton ME, Petrovski G (2013) Autophagy and heterophagy dysregulation leads to retinal pigment epithelium dysfunction and development of age-related macular degeneration. Autophagy 9: 973984. https://doi.org/10.4161/auto. 24546

Kaarniranta K, Tokarz P, Koskela A, Paterno J, Blasiak J (2017) Autophagy regulates death of retinal pigment epithelium cells in agerelated macular degeneration. Cell Biol Toxicol 33: 113-128. https:// doi.org/10.1007/s10565-016-9371-8

Kallay E, Bareis P, Bajna E, Kriwanek S, Bonner E, Toyokuni S, Cross HS (2002) Vitamin d receptor activity and prevention of colonic hyperproliferation and oxidative stress. Food Chem Toxicol 40: 11911196

Kanaki T, Makrantonaki E, Zouboulis CC (2016) Biomarkers of skin aging. Rev Endocr Metab Disord 17: 433-442. https://doi. org/10.1007/s11154-016-9392-x

Katoh M (2013) Therapeutics targeting angiogenesis: Genetics and epigenetics, extracellular mirnas and signaling networks (review). Int J Mol Med 32: 763-767. https://doi.org/10.3892/ijmm.2013.1444

Kauppinen A, Paterno JJ, Blasiak J, Salminen A, Kaarniranta K (2016) Inflammation and its role in age-related macular degeneration. Cell Mol Life Sci 73: 1765-1786. https://doi.org/10.1007/s00018-0162147-8

Kernacki KA, Berk RS (1994) Characterization of the inflammatory response induced by corneal infection with pseudomonas aeruginosa. J Ocul Pharmacol 10: 281-288

Kim EC, Han K, Jee D (2014) Inverse relationship between high blood 25-hydroxyvitamin d and late stage of age-related macular degeneration in a representative korean population. Invest Ophthalmol Vis Sci 55: 4823-4831. https://doi.org/10.1167/iovs.14-14763

Kim HJ, Ji M, Song J, Moon HW, Hur M, Yun YM (2017) Clinical utility of measurement of vitamin d-binding protein and calculation of bioavailable vitamin $\mathrm{d}$ in assessment of vitamin $\mathrm{d}$ status. Ann Lab Med 37: 34-38. https://doi.org/10.3343/alm.2017.37.1.34

Kinyamu HK, Gallagher JC, Petranick KM, Ryschon KL (1996) Effect of parathyroid hormone (hpth[1-34]) infusion on serum 1,25-dihydroxyvitamin $\mathrm{d}$ and parathyroid hormone in normal women. $J$ Bone Miner Res 11: 1400-1405. https://doi.org/10.1002/jbmr.5650111005

Kozlowski MR (2015) The arpe-19 cell line: Mortality status and utility in macular degeneration research. Curr Eye Res 40: 501-509. https://doi.org/10.3109/02713683.2014.935440

Kwa FA, Thrimawithana TR (2014) Epigenetic modifications as potential therapeutic targets in age-related macular degeneration and 
diabetic retinopathy. Drug Discov Today 19: 1387-1393. https://doi. org/10.1016/j.drudis.2014.03.026

Lee V, Rekhi E, Hoh Kam J, Jeffery G (2012) Vitamin d rejuvenates aging eyes by reducing inflammation, clearing amyloid beta and improving visual function. Neurobiol Aging 33: 2382-2389. https://doi. org/10.1016/j.neurobiolaging.2011.12.002

Li YJ, Jiang Q, Cao GF, Yao J, Yan B (2015) Repertoires of autophagy in the pathogenesis of ocular diseases. Cell Physiol Biochem 35: 16631676. https://doi.org/10.1159/000373980

Liao SM, Zheng W, Zhu J, Lewis CA, Delgado O, Crowley MA, Buchanan NM, Jaffee BD, Dryja TP (2017) Specific correlation between the major chromosome $10 \mathrm{q} 26$ haplotype conferring risk for age-related macular degeneration and the expression of htra1. Mol is 23: 318-333

Liu MM, Chan CC, Tuo J (2012) Genetic mechanisms and age-related macular degeneration: Common variants, rare variants, copy number variations, epigenetics, and mitochondrial genetics. Hum Genomics 6: 13. https://doi.org/10.1186/1479-7364-6-13

Lyzogubov VV, Bora PS, Wu X, Horn LE, de Roque R, Rudolf XV, Atkinson JP, Bora NS (2016) The complement regulatory protein cd46 deficient mouse spontaneously develops dry-type age-related macular degeneration-like phenotype. Am J Pathol. https://doi. org/10.1016/j.ajpath.2016.03.021

MacLaughlin J, Holick MF (1985) Aging decreases the capacity of human skin to produce vitamin d3. I Clin Invest 76: 1536-1538. https://doi.org/10.1172/jci112134

Maguire O, Campbell MJ (2010) Vitamin d and p53-differentiating their relationship in aml. Cancer Biol Ther 10: 351-353

Mangin M, Sinha R, Fincher K (2014) Inflammation and vitamin d: The infection connection. Inflamm Res 63: 803-819. https://doi. org/10.1007/s00011-014-0755-z

Mason RS, Sequeira VB, Dixon KM, Gordon-Thomson C, Pobre K, Dilley A, Mizwicki MT, Norman AW, Feldman D, Halliday GM, Reeve VE (2010) Photoprotection by 1alpha,25-dihydroxyvitamin $\mathrm{d}$ and analogs: Further studies on mechanisms and implications for uv-damage. J Steroid Biochem Mol Biol 121: 164-168. https://doi. org/10.1016/j.jsbmb.2010.03.082

McKay GJ, Young IS, McGinty A, Bentham GC, Chakravarthy U, Rahu M, Seland I, Soubrane G, Tomazzoli L, Topouzis F, Vioque J, de Jong PT, Fletcher AE (2017) Associations between serum vitamin $\mathrm{d}$ and genetic variants in vitamin d pathways and age-related macular degeneration in the european eye study. Opbthalmology 124: 90-96. https://doi.org/10.1016/j.ophtha.2016.09.007

Millen AE, Meyers KJ, Liu Z, Engelman CD, Wallace RB, LeBlanc ES, Tinker LF, Iyengar SK, Robinson JG, Sarto GE, Mares JA (2015) Association between vitamin d status and age-related macular degeneration by genetic risk. JAMA Ophthalmol 133: 1171-1179. https://doi.org/10.1001/jamaophthalmol.2015.2715

Millen AE, Nie J, Sahli MW, Mares JA, Meyers KJ, Klein BEK, LaMonte MJ, Lutsey PL, Andrews CA, Klein R (2017) Vitamin d status and prevalent early age-related macular degeneration in african americans and caucasians: The atherosclerosis risk in communities (aric) study. J Nutr Health Aging 21: 772-780. https://doi. org/10.1007/s12603-016-0827-6

Millen AE, Voland R, Sondel SA, Parekh N, Horst RL, Wallace RB, Hageman GS, Chappell R, Blodi BA, Klein ML, Gehrs KM, Sarto GE, Mares JA (2011) Vitamin d status and early age-related macular degeneration in postmenopausal women. Arch Ophthalmol 129: 481489. https://doi.org/10.1001/archophthalmol.2011.48

Mitter SK, Rao HV, Qi X, Cai J, Sugrue A, Dunn WA, Jr., Grant MB, Boulton ME (2012) Autophagy in the retina: A potential role in age-related macular degeneration. Adv Exp Med Biol 723: 83-90. https://doi.org/10.1007/978-1-4614-0631-0_12

Mizushima N (2007) Autophagy: Process and function. Genes Dev 21: 2861-2873. https://doi.org/10.1101/gad.1599207

Morrison MA, Silveira AC, Huynh N, Jun G, Smith SE, Zacharaki F, Sato H, Loomis S, Andreoli MT, Adams SM, Radeke MJ, Jelcick AS, Yuan Y, Tsiloulis AN, Chatzoulis DZ, Silvestri G, Kotoula MG, Tsironi EE, Hollis BW, Chen R, Haider NB, Miller JW, Farrer LA, Hageman GS, Kim IK, Schaumberg DA, DeAngelis MM (2011) Systems biology-based analysis implicates a novel role for vitamin $\mathrm{d}$ metabolism in the pathogenesis of age-related macular degeneration. Hum Genomics 5: 538-568

Nebbioso M, Buomprisco G, Pascarella A, Pescosolido N (2017) Modulatory effects of 1,25-dihydroxyvitamin d3 on eye disorders: A critical review. Crit Rev Food Sci Nutr 57: 559-565. https://doi.org/1 $0.1080 / 10408398.2014 .893504$

Need AG, O'Loughlin PD, Morris HA, Coates PS, Horowitz M, Nordin BE (2008) Vitamin d metabolites and calcium absorption in severe vitamin d deficiency. J Bone Miner Res 23: 1859-1863. https:// doi.org/10.1359/ibmr.080607

Osborn MP, Park Y, Parks MB, Burgess LG, Uppal K, Lee K, Jones DP, Brantley MA, Jr. (2013) Metabolome-wide association study of neovascular age-related macular degeneration. PLoS One 8: e72737. https://doi.org/10.1371/journal.pone.0072737
Pahl L, Schubert S, Skawran B, Sandbothe M, Schmidtke J, Stuhrmann M (2013) 1,25-dihydroxyvitamin d decreases htra1 promoter activity in the rhesus monkey--a plausible explanation for the influence of vitamin $\mathrm{d}$ on age-related macular degeneration? Exp Eye Res 116: 234-239. https://doi.org/10.1016/j.exer.2013.09.012

Parekh N, Chappell RJ, Millen AE, Albert DM, Mares JA (2007) Association between vitamin $\mathrm{d}$ and age-related macular degeneration in the third national health and nutrition examination survey, 1988 through 1994. Arch Ophthalmol 125: 661-669. https://doi. org/10.1001/archopht.125.5.661

Pawlowska E, Wysokinski D, Blasiak J (2016) Nucleotide excision repair and vitamin d--relevance for skin cancer therapy. Int J Mol Sci 17: 372. https://doi.org/10.3390/ijms17040372

Penna G, Adorini L (2000) 1 alpha,25-dihydroxyvitamin d3 inhibits differentiation, maturation, activation, and survival of dendritic cells leading to impaired alloreactive t cell activation. J Immunol 164: 2405-2411

Piotrowska A, Wierzbicka J, Zmijewski MA (2016) Vitamin d in the skin physiology and pathology. Acta Biochim Pol 63: 17-29. https:// doi.org/10.18388/abp.2015_1104

Pludowski P, Holick MF, Grant WB, Konstantynowicz J, Mascarenhas MR, Haq A, Povoroznyuk V, Balatska N, Barbosa AP, Karonova T, Rudenka E, Misiorowski W, Zakharova I, Rudenka A, Lukaszkiewicz J, Marcinowska-Suchowierska E, Laszcz N, Abramowicz P, Bhattoa HP, Wimalawansa SJ (2018) Vitamin d supplementation guidelines. J Steroid Biochem Mol Biol 175: 125-135. https://doi. org/10.1016/j.jsbmb.2017.01.021

Pludowski P, Karczmarewicz E, Bayer M, Carter G, Chlebna-Sokol D, Czech-Kowalska J, Debski R, Decsi T, Dobrzanska A, Franek E, Gluszko P, Grant WB, Holick MF, Yankovskaya L, Konstantynowicz J, Ksiazyk JB, Ksiezopolska-Orlowska K, Lewinski A, Litwin M, Lohner S, Lorenc RS, Lukaszkiewicz J, Marcinowska-Suchowierska E, Milewicz A, Misiorowski W, Nowicki M, Povoroznyuk V, Rozentryt P, Rudenka E, Shoenfeld Y, Socha P, Solnica B, Szalecki M, Talalaj M, Varbiro S, Zmijewski MA (2013) Practical guidelines for the supplementation of vitamin $d$ and the treatment of deficits in central europe - recommended vitamin $\mathrm{d}$ intakes in the general population and groups at risk of vitamin d deficiency. Endokrynol Pol 64: 319-327

Prietl B, Treiber G, Pieber TR, Amrein K (2013) Vitamin d and immune function. Nutrients 5: 2502-2521. https://doi.org/10.3390/ nu5072502

Reibaldi M, Longo A, Pulvirenti A, Avitabile T, Russo A, Cillino S, Mariotti C, Casuccio A (2016) Geo-epidemiology of age-related macular degeneration: New clues into the pathogenesis. Am J Ophthalmol 161: 78-93.e71-72. https://doi.org/10.1016/j.ajo.2015.09.031

Reichrath J (2012) Unravelling of hidden secrets: The role of vitamin d in skin aging. Dermatoendocrinol 4: 241-244. https://doi.org/10.4161/ derm. 21312

Reichrath J, Zouboulis CC, Vogt T, Holick MF (2016) Targeting the vitamin $d$ endocrine system (vdes) for the management of inflammatory and malignant skin diseases: An historical view and outlook. Rev Endocr Metab Disord 17: 405-417. https://doi.org/10.1007/ s11154-016-9353-4

Riachy R, Vandewalle B, Kerr Conte J, Moerman E, Sacchetti P, Lukowiak B, Gmyr V, Bouckenooghe T, Dubois M, Pattou F (2002) 1,25-dihydroxyvitamin $\mathrm{d} 3$ protects rinm5f and human islet cells against cytokine-induced apoptosis: Implication of the antiapoptotic protein a20. Endocrinology 143: 4809-4819. https://doi.org/10.1210/ en.2002-220449

Sarma A, Yang W (2011) Calcium regulation of nucleocytoplasmic transport. Protein Cell 2: 291-302. https://doi.org/10.1007/s13238011-1038-x

Seddon JM, Cote J, Rosner B (2003) Progression of age-related macular degeneration: Association with dietary fat, transunsaturated fat, nuts, and fish intake. Arch Ophthalmol 121: 1728-1737. https://doi. org/10.1001/archopht.121.12.1728

Seddon JM, Reynolds R, Shah HR, Rosner B (2011) Smoking, dietary betaine, methionine, and vitamin $\mathrm{D}$ in monozygotic twins with discordant macular degeneration: Epigenetic implications. Ophthalmology 118: 1386-1394. https://doi.org/10.1016/j.ophtha.2010.12.020

Sharma LK, Dutta D, Sharma N, Gadpayle AK (2017) The increasing problem of subclinical and overt hypervitaminosis $d$ in india: An institutional experience and review. Nutrition 34: 76-81. https://doi. org/10.1016/j.nut.2016.09.014

Shen L, Ji HF (2015) Vitamin d deficiency is associated with increased risk of alzheimer's disease and dementia: Evidence from meta-analysis. Nutr J 14: 76. https://doi.org/10.1186/s12937-015-0063-7

Shibutani ST, Saitoh T, Nowag H, Munz C, Yoshimori T (2015) Autophagy and autophagy-related proteins in the immune system. Nat Immunol 16: 1014-1024. https://doi.org/10.1038/ni.3273

Shokravi MT, Marcus DM, Alroy J, Egan K, Saornil MA, Albert DM (1995) Vitamin d inhibits angiogenesis in transgenic murine retinoblastoma. Invest Ophthalmol Vis Sci 36: 83-87 
Sikora E, Bielak-Zmijewska A, Mosieniak G (2014) Cellular senescence in ageing, age-related disease and longevity. Curr Vasc Pharmacol 12: $698-706$

Singh A (2014) Systemic changes in neovascular age-related macular degeneration. Dan Med J 61: B4872.

Stevens R, Bartlett H, Cooke R (2015) Dietary analysis and nutritional behaviour in people with and without age-related macular disease. Clin Nutr ESPEN 10: e112-e117. https://doi.org/10.1016/j.clnesp.2015.03.080

Suh HW, Kim JK, Kim TS, Jo EK (2017) New insights into vitamin d and autophagy in inflammatory bowel diseases. Curr Med Chem 24: 898-910. https://doi.org/10.2174/0929867323666161202151856

Suzuki T, Sano Y, Kinoshita S (2000) Effects of 1alpha,25-dihydroxyvitamin $\mathrm{d} 3$ on langerhans cell migration and corneal neovascularization in mice. Invest Ophthalmol Vis Sci 41: 154-158

Suzuki T, Sano Y, Sotozono C, Kinoshita S (2000) Regulatory effects of 1alpha,25-dihydroxyvitamin $\mathrm{d}(3)$ on cytokine production by human corneal epithelial cells. Curr Eye Res 20: 127-130

Synowiec E, Blasiak J, Zaras M, Szaflik J, Szaflik JP (2012) Association between polymorphisms of the DNA base excision repair genes mutyh and hogg1 and age-related macular degeneration. Exp Eye Res 98: 58-66. https://doi.org/10.1016/j.exer.2012.02.008

Szaflik JP, Janik-Papis K, Synowiec E, Ksiazek D, Zaras M, Wozniak K, Szaflik J, Blasiak J (2009) DNA damage and repair in agerelated macular degeneration. Mutat Res 669: 169-176. https://doi. org/10.1016/j.mrfmmm.2009.06.008

Tulk SE, Liao KC, Muruve DA, Li Y, Beck PL, MacDonald JA (2015) Vitamin d(3) metabolites enhance the nlrp3-dependent secretion of il-1beta from human thp-1 monocytic cells. J Cell Biochem 116: 711720. https://doi.org/10.1002/jcb.24985

Underwood BR, Imarisio S, Fleming A, Rose C, Krishna G, Heard P, Quick M, Korolchuk VI, Renna M, Sarkar S, Garcia-Arencibia M, O'Kane CJ, Murphy MP, Rubinsztein DC (2010) Antioxidants can inhibit basal autophagy and enhance neurodegeneration in models of polyglutamine disease. Hum Mol Genet 19: 3413-3429. https:// doi.org/10.1093/hmg/ddq253
Uro M, Beauchet O, Cherif M, Graffe A, Milea D, Annweiler C (2015) Age-related vitamin d deficiency is associated with reduced macular ganglion cell complex: A cross-sectional high-definition optical coherence tomography study. PLoS One 10: e0130879. https://doi. org/10.1371/journal.pone.0130879

Wang J, Lian H, Zhao Y, Kauss MA, Spindel S (2008) Vitamin d3 induces autophagy of human myeloid leukemia cells. I Biol Chem 283: 25596-25605. https://doi.org/10.1074/jbc.M801716200

Wang JJ, Rochtchina E, Lee AJ, Chia EM, Smith W, Cumming RG, Mitchell P (2007) Ten-year incidence and progression of age-related maculopathy: The blue mountains eye study. Ophthalmology 114: 9298. https://doi.org/10.1016/j.ophtha.2006.07.017

Wong G, Gupta R, Dixon KM, Deo SS, Choong SM, Halliday GM, Bishop JE, Ishizuka S, Norman AW, Posner GH, Mason RS (2004) 1,25-dihydroxyvitamin $\mathrm{d}$ and three low-calcemic analogs decrease uv-induced DNA damage via the rapid response pathway. I Steroid Biochem Mol Biol 89-90: 567-570. https://doi.org/10.1016/j.jsbmb.2004.03.072

Wu S, Sun J (2011) Vitamin d, vitamin d receptor, and macroautophagy in inflammation and infection. Discov Med 11: 325-335.

Xiong Y, Lou Y, Su H, Fu Y, Kong J (2016) Cholecalciterol cholesterol emulsion ameliorates experimental colitis via down-regulating the pyroptosis signaling pathway. Exp Mol Pathol 100: 386-392. https:// doi.org/10.1016/j.yexmp.2016.03.003

Xu G, Wang J, Gao GF, Liu CH (2014) Insights into battles between mycobacterium tuberculosis and macrophages. Protein Cell 5: 728736. https://doi.org/10.1007/s13238-014-0077-5

Yu B, Egbejimi A, Dharmat R, Xu P, Zhao Z, Long B, Miao H, Chen R, Wensel TG, Cai J, Chen Y (2018) Phagocytosed photoreceptor outer segments activate mtorc1 in the retinal pigment epithelium. Sci Signal 11. https://doi.org/10.1126/scisignal.aag3315

Yuk JM, Jo EK (2013) Crosstalk between autophagy and inflammasomes. Mol Cells 36: 393-399. https://doi.org/10.1007/s10059-0130298-0

Zhou BB, Elledge SJ (2000) The DNA damage response: Putting checkpoints in perspective. Nature 408: 433-439. https://doi. org/10.1038/35044005 